\section{Action of Gastrin in Guinea Pig Oxyntic Cells Studies Using Quantitative Cytochemistry}

A. A. Heldsinger and A. I. Vinik

Department of Internal Medicine, Division of Endocrinology and Metabolism, University of Michigan, Ann Arbor, Michigan 48109 bstract. The mechanism of action of gastrin was investigated using cytochemical quantitation of hydroxyl ion production (HIP) in guinea pig gastric oxyntic mucosa. The reaction depends upon the trapping of $\mathrm{OH}$ ions produced during gastric stimulation and is blocked by the benzimidazole, Hassle 149/94, which inhibits the $\mathrm{K}^{+}+\mathrm{H}^{+}$-ATPase and by acetazolamide, an inhibitor of carbonic anhydrase activity. It is thus a measure of hydroxyl ions produced during stimulation of the oxyntic cell and reflects upon hydrogen ion production.

Gastrin $\left(2.5 \times 10^{-16}-2.5 \times 10^{-12} \mathrm{M}\right)$ caused a linear dose-dependent stimulation of HIP in the oxyntic cells. The response was biphasic, with an early peak at $90 \mathrm{~s}$ and a secondary rise at $240 \mathrm{~s}$, which persisted for $10 \mathrm{~min}$. Natural human gastrin (sulfated and nonsulfated) and the active $\mathrm{COOH}$-terminal octapeptide fragment of gastrin stimulated HIP, whereas the biologically inert $\mathrm{NH}_{2}$-terminal (1-13) fragment of gastrin had no effect. The activation of oxyntic cell HIP by gastrin was neutralized by an antiserum directed towards the $\mathrm{COOH}$-terminus of gastrin and not by nonimmune serum.

Cimetidine $\left(10^{-5} \mathrm{M}\right)$ blocked $25 \%$ and atropine $\left(10^{-5}\right.$ $M)$ had no effect on gastrin-stimulated HIP. EGTA $\left(10^{-3}\right.$ M) and $\mathrm{LaCl}_{3}\left(10^{-3} \mathrm{M}\right)$ inhibited the action of gastrin by 67 and 52\%, respectively. The calmodulin antagonists, trifluoperazine $\left(10^{-5} \mathrm{M}\right)$, pimozide $\left(10^{-5} \mathrm{M}\right)$, and the naphthalene sulfonamides, W-7 and W-13 $\left(10^{-5} \mathrm{M}\right)$, inhibited gastrin-stimulated HIP by $45.638 .5,42.3$, and $37.2 \%$, respectively. Higher doses of W-7 and W-13 $\left(10^{-4}\right.$ $M$ ) inhibited gastrin-stimulated HIP by 83 and $67 \%$. The $\mathrm{Ca}^{2+}$ ionophore, A23187 $\left(10^{-4} \mathrm{M}\right)$, stimulated HIP. Thus,

Address correspondence to Dr. Vinik.

Received for publication 28 October 1982 and in revised form 22 March 1984.

J. Clin. Invest.

(c) The American Society for Clinical Investigation, Inc.

0021-9738/84/07/0124/09 \$1.00

Volume 74, July 1984, 124-132 it appears that gastrin stimulation of HIP is complex. $25 \%$ of its action is via a histamine-dependent pathway. $45 \%$ of its action is dependent upon extracellular $\mathrm{Ca}^{2+}$. Its action is also in part dependent upon $\mathrm{a} \mathrm{Ca}^{2+} / \mathrm{cal}-$ modulin mechanism.

\section{Introduction}

Gastrin is a polypeptide hormone produced and secreted by the $G$ cells, which are located in the gastric antral mucosa $(1,2)$. The two major biologically active components of gastrin in the circulation are the heptadecapeptide (G17) and the $\mathrm{NH}_{2}$-extended G34 peptides, which occur in sulfated and nonsulfated forms $(3,4)$. The secretory activity of gastrin resides in the carboxyterminal tetrapeptide amide (5). Although factors regulating gastrin secretion have been characterized (6), little is known of its mechanism of action. Recently, an iodinated form of gastrin with defined biological activity served as a ligand for receptor studies (7). In these studies, binding of radioiodinated gastrin and gastrin analogues to rat gastric mucosal membrane preparations was correlated with the physiological action of gastrin. However, gastric membranes derive from tissues of heterogeneous cell populations and part of the actions of gastrin may have been mediated indirectly.

Although gastrin is a potent acid secretagogue in vivo (8), studies on its mechanism of action have been limited by insensitivity of various in vitro models. Furthermore, there are major discrepancies in the studies carried out in different species. Isolated rabbit gastric glands (8) were unresponsive to pentagastrin or gastrin and were only responsive in the presence of isobutylmethylzanthine (9). In canine parietal cells, only a 10 $15 \%$ increase in $\mathrm{O}_{2}$ consumption (10) and a small (1-2\%) increase in the ${ }^{14} \mathrm{C}$-aminopyrine accumulation were found $(11,12)$.

In the rat isolated gastric cells, gastrin is ineffective in stimulating ${ }^{14} \mathrm{C}$-aminopyrine accumulation (13). Salganik (14), however, showed that gastrin stimulated adenylatecyclase and acid secretion in the rat stomach, increased carbonic anhydrase,

1. Abbreviations used in this paper: W-7, (N-(6-aminohexyl)-5-chloro1-naphthalene sulfonamide); W-13, (N-(4-aminobutyl)-5-chloro-2naphthalene sulfonamide); $D_{50}$, half maximal effects; HIP, hydroxyl ion production; NHG-34, natural human gastrin. 
and activated histidine decarboxylase. He proposed that gastrin stimulated protein synthesis and activated histamine production and release. This sequence is compatible with the Code hypothesis (15), which was originally proposed by McIntosh (16), that histamine is the final common mediator of acid secretion for all secretagogues. However, this appears to be unique to the rat and accounts for only a small fraction of the action of gastrin in rabbit gastric glands (17).

Loveridge et al. $(18,19)$ showed that pentagastrin caused a dose-related increase in parietal cell carbonic anhydrase activity in segments of guinea pig fundus. We have developed the technique $(20,21)$ to quantitate hydroxyl ion production (HIP) ${ }^{1}$ in $18-\mu \mathrm{m}$ sections of guinea pig fundic mucosa, and examined the mechanism of action of gastrin in the oxyntic cell. Our data indicate that gastrin rapidly ( $90 \mathrm{~s}$ ) activates the oxyntic cell by complex mechanisms that are partially histamine, calcium, and calmodulin dependent.

\section{Methods}

Female Hartley albino guinea pigs weighing 400-500 g were fasted for $24 \mathrm{~h}$, asphyxiated in an atmosphere of nitrogen, and the stomach was rapidly removed. A 3-4-cm strip of gastric fundus was excised from a standard area just below the esophagogastric junction. The strip was rinsed in $0.025 \mathrm{M}$ Hepes ( $\mathrm{pH} 7.0$ ) and divided into 5-mm pieces. These pieces were snap-frozen in a beaker that contained a hexane freezing mixture. The frozen pieces were used within $72 \mathrm{~h}$ of freezing.

Sections $18 \mu \mathrm{m}$ thick were cut from the mounted tissue in a cryostat $\left(-20^{\circ} \mathrm{C}\right)$; they were transferred to glass slides, which were stored no longer than $6 \mathrm{~h}$ in the cryostat chamber before use in the assay. The sections were placed flat, sections upwards, in a slide tray, and were allowed to equilibrate at room temperature for $10 \mathrm{~min}$. The test solutions, gastrin, gastrin antiserum, histamine, cimetidine, atropine, $\mathrm{LaCl}_{3}, \mathrm{EGTA}$ acetazolamide, $\mathrm{NaSCN}$, and trifluoperazine were diluted in $0.025 \mathrm{M}$ Hepes ( $\mathrm{pH} 7.0$ ) to the desired concentration. Pimozide, Hassle compound H149/94, A23187, W-7, and W-13 were first dissolved in ethanol and then further diluted in $0.025 \mathrm{M}$ Hepes buffer. Hepes buffer contains $\mathrm{Ca}^{2+}\left(2.1 \times 10^{-7} \mathrm{M}\right), \mathrm{Mg}^{2+}\left(3.7 \times 10^{-7} \mathrm{M}\right)$, and $\mathrm{Cl}^{-}\left(1.2 \times 10^{-6} \mathrm{M}\right)$. ATP in sections of fundus was extracted into a tri- $N$-octylamine/Freon mixture and levels were determined using high pressure liquid chromatography (22). The mean concentration of ATP in the sections was $0.19 \mathrm{mmol} / \mathrm{g}$ dry weight.

Concentrations of gastrin in test solutions were confirmed by radioimmunoassay of the concentrates before serial dilutions. $250 \mu \mathrm{l}$ of test solution was delivered by a dispensing apparatus that was designed to deliver precise volumes of test solution directly and simultaneously onto 24 sections. The time course for the reaction was estimated with exposure of the sections for $30 \mathrm{~s}-10 \mathrm{~min}$. Further studies related to the early response, and the reaction was allowed to continue for $90 \mathrm{~s}$ and then was terminated by the addition of the staining reagents. Within each experiment, each test solution was reacted with the tissue in triplicate. Hydroxyl ion production was quantitated by a modification of Hansson's method (23), which was developed to quantitate catalysis by the enzyme carbonic anhydrase using $10.5 \mathrm{mM} \mathrm{CoSo}_{4}, 53 \mathrm{mM} \mathrm{H}_{2} \mathrm{SO}_{4}, 1.17 \mathrm{mM}$ $\mathrm{KH}_{2} \mathrm{PO}_{4}$, and $157 \mathrm{mM} \mathrm{NaHCO}$ in $0.1 \mathrm{M}$ Hepes (pH 7.4) with $0.001 \%$ gum tragacanth. The freshly prepared staining solution was poured over the slides so as just to cover them. The staining reaction was allowed to proceed for $2 \mathrm{~min}$ at $20^{\circ} \mathrm{C}$ with gentle agitation. The slides were washed twice in distilled water and immersed in a saturated solution of $\mathrm{H}_{2} \mathrm{~S}$ in water for $90 \mathrm{~s}$. The slides were again washed in distilled water and mounted in Farrants medium. The staining procedure led to the formation of a visible brown precipitate of $\mathrm{CoS}$ within the section. The most deeply stained cells were the oxyntic cells. The amount of reaction product in each cell is a reflection of the number of hydroxyl ions trapped (8) and was measured by means of a Vickers M85 scanning and integrating microdensitometer (Vickers Instruments, Croydon, England). The cells selected for each reading were those that completely filled a mask which, when used with a $25 \times$ objective, had a field diameter of $20 \mu \mathrm{m} .20$ oxyntic cells in a randomized field in each section were read. The same number of readings were made in the muscularis mucosa in each section. Readings from the muscularis mucosa reflect the nonspecific adsorption of $\operatorname{CoS}$ to the tissue and the light scattering by the tissue, and were therefore subtracted from those of the oxyntic cells. To correct for possible instrument variation, the microdensitometer was calibrated by taking readings of a standard filter of known optical density before and after taking readings from each section. These determinations were used to calculate the integrated extinction and was expressed as a percentage using the following equation: (mean extinction of oxyntic cells)-(mean extinction of muscularis mucosa) $\times 100 / d_{1}$, where $d_{1}$ is the reading of a standard filter with the optical density of 1 . The coefficient of variation of the extinction readings on 20 cells in a section varied from 4.1 to $7.8 \%$.

The coefficient of variation for cells stimulated by a $10^{-12} \mathrm{M}$ dose of gastrin in different sections taken from different animals was $4.6 \%$. All experiments were carried out in a minimum of three animals with at least six replicates for each data point. By analysis of covariance, no significant differences were found between guinea pigs and data from different animals were pooled. The effects of time of exposure to gastrin were similarly evaluated by using data from each time point in the treated and untreated tissues. Since $10^{-12} \mathrm{M}$ gastrin proved to be the most efficacious concentration, its effect was ascribed the arbitrary value of $100 \%$. The efficacy of other concentrations was computed as a percentage of that of $10^{-12} \mathrm{M}$ gastrin. The doses required to produce half maximal effects $\left(D_{50}\right)$ were computed from the concentration of agonist required for the $D_{50}$. The potency for each secretagogue tested was related to the concentration required to achieve the $D_{50}$ effect relative to that of gastrin. The integrated areas of the responses were obtained by calculating the areas under the dose response curves before and after treatment with antagonist at each concentration point.

To determine significance of effects of various antagonists on the responses to gastrin, a quadratic equation was fit to the dose-response model, where response equalled $\mathrm{Co}+\mathrm{Cl}($ dose $)+\mathrm{C} 2$ (dose) $)^{2}$, and was applied to the individual data sets. Within each "drug" set no significant difference between the constants among animals was found. By analysis of covariance estimates of $\mathrm{Cl}, \mathrm{C} 2$, and the slopes of the regression line, significant effects of the antagonists could be discerned. In instances where effects of antagonists on the maximal responsiveness to gastrin were examined, significance of differences at each concentration of antagonist was determined using paired or unpaired $t$ tests, where $n$ was equal to the number of tissue examined.

Materials. Synthetic (15-Leucine) human gastrin I was obtained from Research Plus, Inc., Bayonne, NJ. Natural human heptadecapeptide, sulfated and nonsulfated, and natural human gastrin (NHG-34) were obtained from the Center for Ulcer Research and Education (National Institutes of Health, Bethesda, MD). Synthetic fragments of gastrin 113 and 8-17 were generous gifts of J. Morley, Imperial Chemical Industries, London, United Kingdom. The $\mathrm{COOH}$-terminus directed gastrin antiserum was obtained by immunization of rabbits with the $\mathrm{COOH}$ - 
terminus 8-17 synthetic gastrin analogue, which was conjugated to B. cincta haemocyanin using carbodiimide (24). The antiserum was stored at $-20^{\circ} \mathrm{C}$ until use. Histamine dihydrochloride, Hepes, cobalt sulfate, atropine sulfate, lanthanum chloride, gum tragacanth, A23187, and EGTA were obtained from Sigma Chemical Company, St. Louis, MO.

Cimetidine dihydrochloride and trifluoperazine hydrochloride were obtained from Smith, Kline and French Laboratories, Philadelphia, PA, and pimozide was from McNeil Pharmaceutical, Spring House, PA. Acetazolamide was obtained from Lederle Laboratories, Pearl River, NY; sodium thiocyanate was from J. T. Baker Chemical Co., Phillipsburg, $\mathrm{NJ}$; and Hassle compound H149/94 was from A. B. Hassle Co., Molndal, Sweden. W-7 (N-(6-aminohexyl)-5-chloro-1-naphthalene sulfonamide) and W-13 ( $N$-(4-aminobutyl)-5-chloro-2-naphthalene sulfonamide) were obtained from Caabco, Inc., Houston, TX.

Hartley albino guinea pigs were obtained from Charles River Breeding Laboratories, Wilmington, MA, and Farrants medium was from Biomedical Specialties, Santa Monica, CA.

\section{Results}

Time course of response to gastrin. Gastrin $\left(2.5 \times 10^{-12} \mathrm{M}\right)$ was reacted with fundic tissue sections for time periods of $30 \mathrm{~s}-10$ min to determine the time course of oxyntic cell HIP. As shown in Fig. 1, gastrin $\left(2.5 \times 10^{-12} \mathrm{M}\right)$ caused a maximal increase in HIP at $90 \mathrm{~s}(P<0.01)$ and HIP fell off rapidly at $120 \mathrm{~s}$ of exposure. Increasing the exposure time to 4-10 min led to a second phase wherein maximal HIP at $240 \mathrm{~s}$ was similar to that found at $90 \mathrm{~s}$.

Dose response to gastrin. A dose response curve was established for gastrin $\left(2.5 \times 10^{-16}-2.5 \times 10^{-6} \mathrm{M}\right)$. As shown in Fig. 2 , gastrin caused a significant increase in HIP above basal from $2.5 \times 10^{-14} \mathrm{M}(P<0.001)$ and reached a maximum at 2.5 $\times 10^{-12} \mathrm{M}(P<0.001)$. Increasing doses of gastrin to 2.5 $\times 10^{-6} \mathrm{M}$ caused a slight reduction in HIP below the maximal response. Concentrations of gastrin in the incubate were confirmed by radioimmunoassay (24). There were no changes after exposure of the tissues to gastrin. Furthermore, there was no

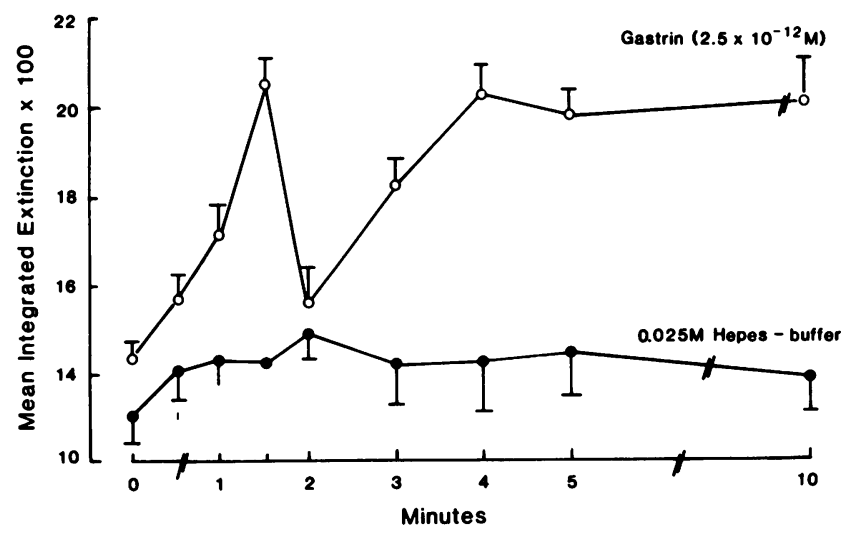

Figure 1. The effects of gastrin $\left(2.5 \times 10^{-12} \mathrm{M}\right)$ and Hepes buffer reacted with guinea pig oxyntic cells for different time periods. Integrated extinction is a reflection of HIP. These experiments were done in duplicate on three separate animals for each time point.

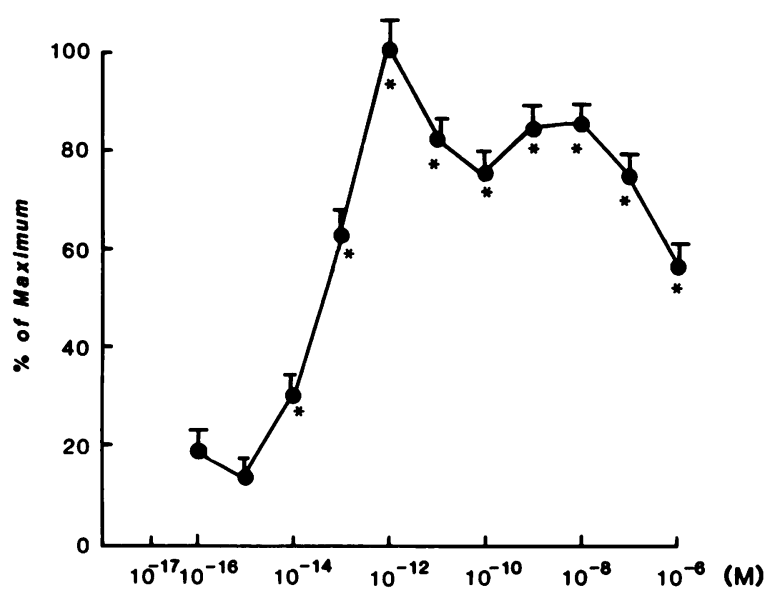

Figure 2. The effects of increasing doses of gastrin on oxyntic cell HIP. *Indicates significant differences from basal activity $(P$ $<0.001)$.

evidence of significant concentration of ${ }^{125} \mathrm{I}$-labeled gastrin by the tissue.

Stimulation of HIP by gastrin analogues. To determine the specificity of gastrin-stimulated oxyntic cell HIP, various synthetic analogues with established in vivo secretory potential were examined. Dose-response curves $\left(1 \times 10^{-16}-1 \times 10^{-12} \mathrm{M}\right)$ were generated for (a) NHG-34 sulfated, (b) NHG-34 nonsulfated, (c) natural human gastrin 1-34, (d) CCK-octapeptide, $(e)$ the $\mathrm{NH}_{2}$-terminal biologically inactive $1-13$ portion of the gastrin molecule, and $(f)$ the $\mathrm{COOH}$-terminal biologically active synthetic gastrin 8-17 fragment. The stimulation of HIP by various natural and synthetic gastrin peptides is shown in Table I. NHG-

Table I. Comparison of Potency of Synthetic and Natural Gastrins on Oxyntic Cell HIP

\begin{tabular}{ll}
\hline Peptide & $\begin{array}{l}\text { Relative potency* } \\
\text { (molar ratio) }\end{array}$ \\
\hline NHG-17-I & 1.20 \\
NHG-17-II & 1.12 \\
NHG-34-I & 0.67 \\
CCK octapeptide & 0.07 \\
Synthetic gastrin 8-17 & 1.00 \\
Synthetic gastrin 1-13 & 0.00 \\
Bombesin, insulin, glucagon, and VIP caused no & \\
$\quad$ stimulation of HIP &
\end{tabular}

* The data were calculated from the molar concentration required to produce half-maximal stimulation of HIP and are given as the molar ratio compared with synthetic heptadecapeptide gastrin, which was used as the reference preparation. NHG, natural human gastrin; I, nonsulfated; II, sulfated; CCK-octapeptide, the $\mathrm{COOH}$-terminal portion of cholecystokinin-pancreazymin, and $1-13$ and 8-17 refer to synthetic $\mathrm{NH}_{2}$ - and $\mathrm{COOH}$-terminal fragments of gastrin, VIP, vasoactive intestinal peptide. 
34 sulfated and nonsulfated, were both slightly but not significantly more potent than synthetic gastrin. The $\mathrm{COOH}$-terminal synthetic gastrin 8-17 fragment, which is the active portion of the molecule, had activity that was equivalent to that of the whole molecule. NHG-34 (G34) was less potent than synthetic heptadecapeptide or the G8-17 fragment. The COOH-terminal synthetic octapeptide of CCK8 had similar efficacy to the active fragments of gastrin but less potency. The $\mathrm{NH}_{2}$-terminal 1-13 fragment of gastrin, which is the biologically inactive portion, did not stimulate HIP.

Inhibition of gastrin-stimulated HIP. There are no established biochemical antagonists of the action of gastrin. Therefore, the ability to neutralize the action of gastrin was examined by reacting tissues with a region-specific antiserum. A 1/1,000 dilution of an antiserum specific for the biologically active $\mathrm{COOH}$-terminus of gastrin was incubated in combination with gastrin $\left(2.5 \times 10^{-15}-2.5 \times 10^{-11} \mathrm{M}\right)$. As shown in Fig. 3, stimulation of HIP by gastrin was inhibited at all concentrations of gastrin tested in the presence of the $\mathrm{COOH}$-terminus antiserum $(P$ $<0.001$ ), but was not inhibited by nonimmune serum. The $\mathrm{COOH}$-terminus antiserum had no effect on HIP stimulated by histamine. To determine whether the actions of gastrin were mediated via histamine or acetylcholine, the effects of cimetidine, the $\mathrm{H}_{2}$ histamine blocker, and atropine, the muscarinic cholinergic blocker, on gastrin-stimulated HIP were examined. The doses of antagonist chosen were those causing maximal inhibition of histamine and carbamylcholine-stimulated HIP, respectively (26).

Cimetidine $\left(10^{-5} \mathrm{M}\right)$ and atropine $\left(10^{-5} \mathrm{M}\right)$ were added to a $D_{\max }$ dose of gastrin $\left(2.5 \times 10^{-12} \mathrm{M}\right)$ separately and in combination. Cimetidine reduced the effect of gastrin by $23 \%$ and atropine had no effect (Fig. 4). In combination, cimetidine and atropine reduced the response to gastrin by $30 \%$, which was not significantly different from the effect of cimetidine alone. In studies previously reported, cimetidine $\left(10^{-5} \mathrm{M}\right)$ inhibited maximal histamine-stimulated HIP by $74.5 \%$ (26), and atropine

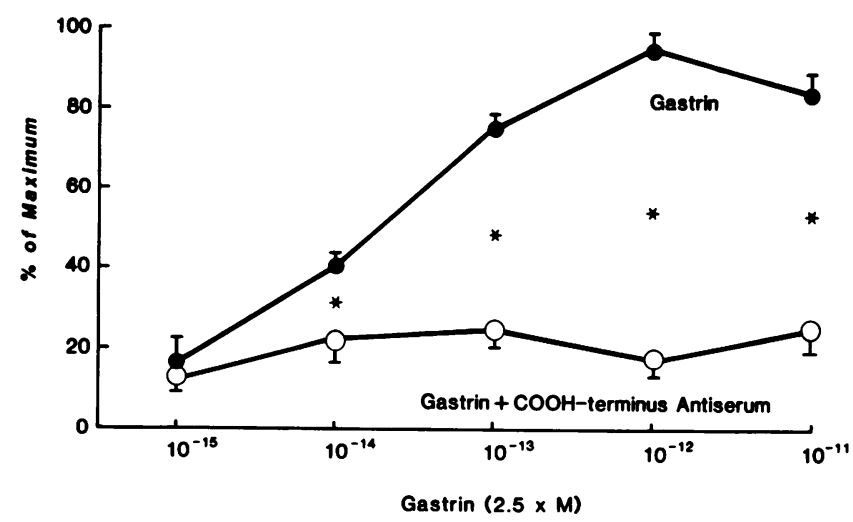

Figure 3. The effects of $\mathrm{COOH}$-terminus antiserum on gastrin-stimulated oxyntic cell HIP. *Indicates significant differences between gastrin alone and gastrin plus $\mathrm{COOH}$-terminus antiserum $(P<0.001)$.

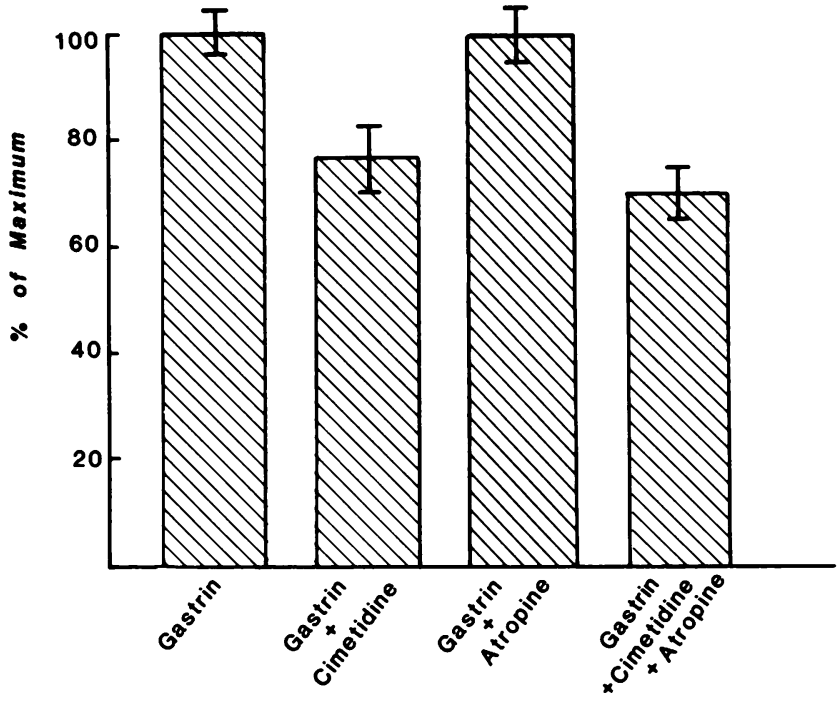

Figure 4. The effects of cimetidine $\left(10^{-5} \mathrm{M}\right)$ and atropine $\left(10^{-5} \mathrm{M}\right)$ on maximal gastrin-stimulated oxyntic cell HIP.

$\left(10^{-5} \mathrm{M}\right)$ completely abolished the effects of carbachol-stimulated HIP (26).

Calcium dependence of gastrin activity. In studies previously reported (20), $\mathrm{Ca}^{2+}\left(10^{-6}-10^{-3} \mathrm{M}\right)$ stimulated oxyntic cell HIP, which was maximal at $10^{-4} \mathrm{M}$. The effects of EGTA $\left(10^{-6}\right.$ $\left.10^{-3} \mathrm{M}\right)$ on $\mathrm{Ca}^{2+}\left(10^{-4} \mathrm{M}\right)$-stimulated and basal HIP was investigated. As shown in Fig. 5, EGTA significantly inhibited $\mathrm{Ca}^{2+}$-stimulated HIP $(P<0.005)$ in a dose-dependent manner, but was not equivalent on a mole for mole basis, which was presumably due to endogenous $\mathrm{Ca}^{2+}$ present in the tissue. EGTA

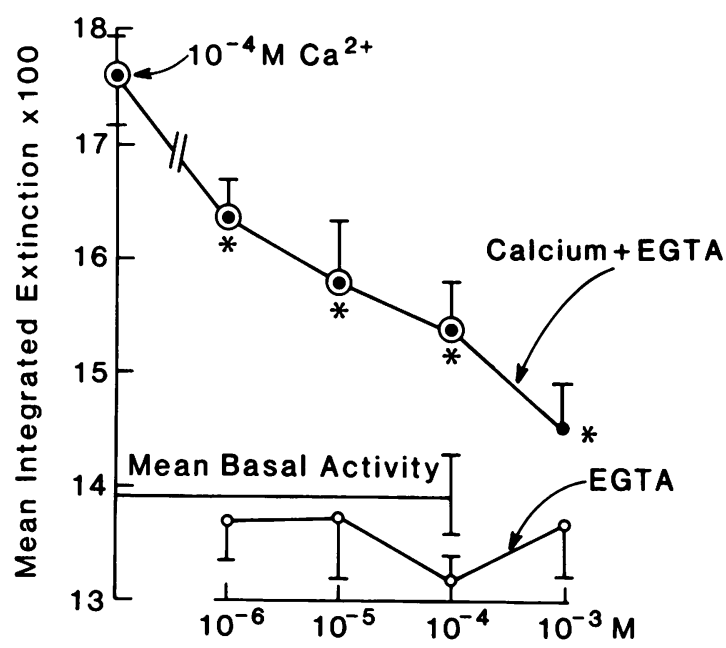

Figure 5. The effects of EGTA $\left(10^{-6}-10^{-3} \mathrm{M}\right)$ on basal- and calcium $\left(10^{-4} \mathrm{M}\right)$-stimulated oxyntic cell HIP. Integrated extinction is a reflection of HIP. *Indicates significant differences from $\mathrm{Ca}^{2+}\left(10^{-4} \mathrm{M}\right)$ $(P<0.005)$. The 0 indicates significant increases above basal activity. 
$\left(10^{-3} \mathrm{M}\right)$ neutralized all the action of a $\mathrm{D}_{\max }$ dose of $\mathrm{Ca}^{2+}$. EGTA caused a slight but not significant decrease in basal HIP. The effect of increased extracellular $\mathrm{Ca}^{2+}$ on gastrin-stimulated HIP was examined by generating a gastrin dose-response curve ( 2.5 $\left.\times 10^{-15}-2.5 \times 10^{-11} \mathrm{M}\right)$ in the presence of $\mathrm{Ca}^{2+}\left(10^{-6}-10^{-4} \mathrm{M}\right)$. As shown in Fig. 6, addition of extracellular $\mathrm{Ca}^{2+}$ caused a significant increase in gastrin action which was above that of gastrin alone at the lower range of the dose-response curve $\left(10^{-15}\right.$ and $\left.10^{-14} \mathrm{M}\right)(P<0.05)$.

The role of extracellular calcium in gastrin-stimulated HIP was determined by examining the effects of EGTA $\left(10^{-6}-10^{-3}\right.$ M) on maximally gastrin $\left(2.5 \times 10^{-12} \mathrm{M}\right)$-stimulated HIP. As shown in Fig. 7, gastrin-stimulated HIP was significantly inhibited by EGTA $\left(10^{-6}-10^{-3} \mathrm{M}\right)(P<0.005)$ in a dose-dependent manner. To determine whether bidirectional flux of $\mathrm{Ca}^{2+}$ was important in the action of gastrin, lanthanum chloride $\left(10^{-6}\right.$ $\left.10^{-3} \mathrm{M}\right)$ was added to a $\mathrm{D}_{\max }$ dose of gastrin. $\mathrm{LaCl}_{3}\left(10^{-6}-10^{-3}\right.$ M) significantly reduced gastrin-stimulated HIP in a dose-independent manner $(P<0.005)$. $\mathrm{LaCl}_{3}\left(10^{-6}-10^{-3} \mathrm{M}\right)$ caused a slight but not significant increase in basal HIP. EGTA and $\mathrm{LaCl}_{3}$ had no effect on histamine-stimulated HIP (20). To determine whether enhanced $\mathrm{Ca}^{2+}$ influx was a stimulus for HIP, the effects of the $\mathrm{Ca}^{2+}$ ionophore, A23187, on basal and maximal gastrinstimulated HIP was examined. A23187 caused a significant increase in basal HIP $(P<0.01)$ but paradoxically inhibited the maximal effect of gastrin $(P<0.001)$ (Fig. 7). To determine if calmodulin played a role in mediating gastrin-stimulated HIP, the calmodulin antagonists, trifluoperazine $\left(10^{-5} \mathrm{M}\right)$ and pimozide $\left(10^{-5} \mathrm{M}\right)$, were added to each concentration of gastrin in the dose-response curve $\left(2.5 \times 10^{-15}-2.5 \times 10^{-11} \mathrm{M}\right)$. As shown in Fig. 8, pimozide significantly reduced stimulation of HIP by gastrin at $2.5 \times 10^{-12}$ and at $2.5 \times 10^{-11} \mathrm{M}(P<0.05)$. Trifluoperazine significantly reduced stimulation of HIP by gastrin at $2.5 \times 10^{-13}-2.5 \times 10^{-11} \mathrm{M}(P<0.05)$. When measured as the integrated areas of the responses, pimozide caused $38.4 \%$

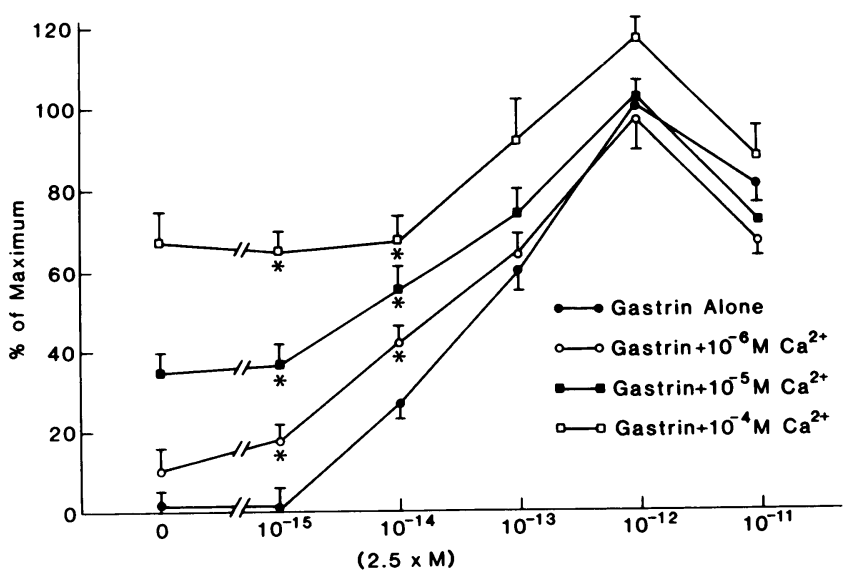

Figure 6. The effects of increasing doses of $\mathrm{Ca}^{2+}\left(10^{-6}-10^{-4} \mathrm{M}\right)$ on gastrin-stimulated oxyntic cell HIP. *Indicates significant differences between gastrin alone and gastrin plus $\mathrm{Ca}^{2+}(P<0.05)$.

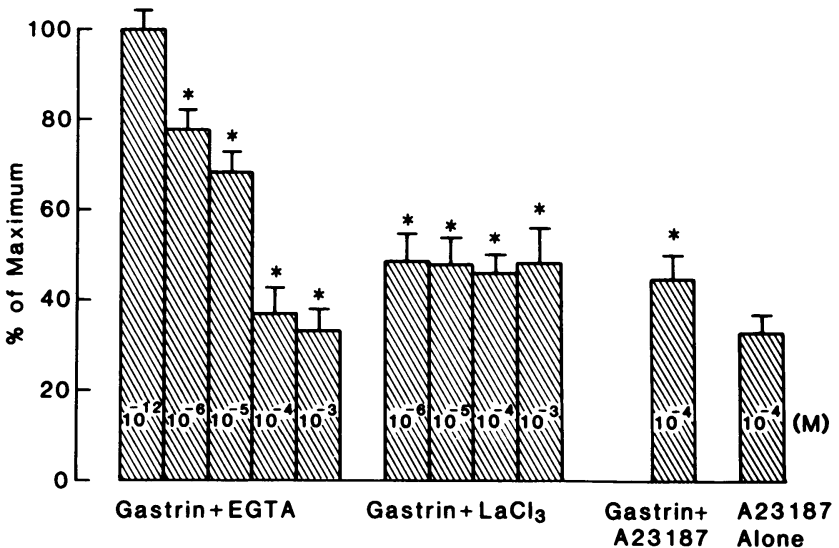

Figure 7. The effects of EGTA $\left(10^{-6}-10^{-3} \mathrm{M}\right)$ and $\mathrm{LaCl}_{3}\left(10^{-6}-10^{-3}\right.$ $\mathrm{M})$ on maximally gastrin-stimulated $\left(10^{-12} \mathrm{M}\right)$ oxyntic cell HIP. ${ }^{*} \mathrm{In}-$ dicates significant differences between gastrin alone and gastrin plus EGTA or $\mathrm{LaCl}_{3}(P<0.05)$. Also shown are the effects of A23187 $\left(10^{-4} \mathrm{M}\right)$ alone and together with gastrin $\left(10^{-12} \mathrm{M}\right)$.

and trifluoperazine $45.6 \%$ inhibition of the action of gastrin. By analysis of covariance, the effects of both drugs were shown to differ significantly from that of gastrin, but not from each other. In parallel studies, trifluoperazine and pimozide inhibited histamine-stimulated HIP by 54 and $56 \%$, respectively (20). Because trifluoperazine and pimozide are highly lipid soluble and may therefore have nonspecific effects on the cell membrane, two additional calmodulin antagonists of different chemical nature were tested. Naphthalene sulfonamides, W-7 $\left(10^{-5} \mathrm{M}\right)$ and $\mathrm{W}-13\left(10^{-5} \mathrm{M}\right)$, were added to each concentration of gastrin in the dose-response curve. As shown in Fig. 9, W-7 and W-13

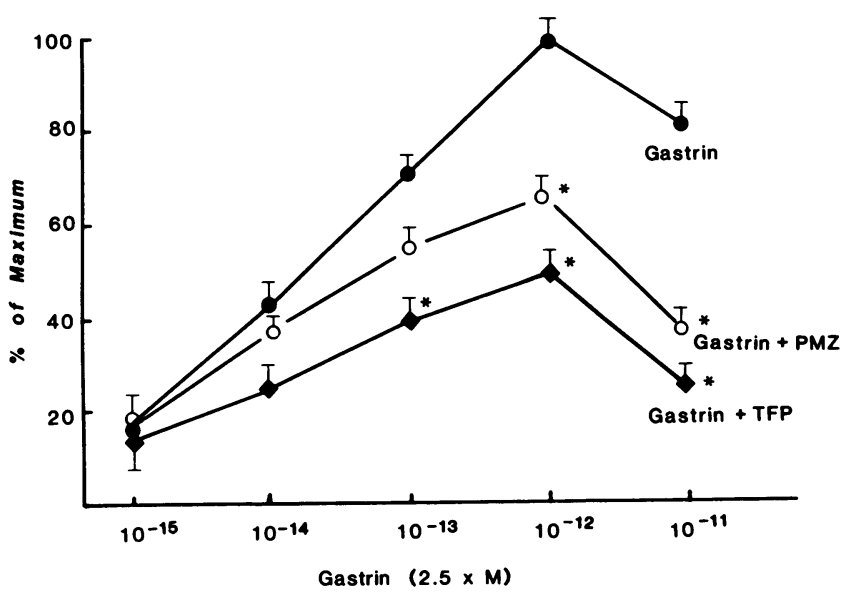

Figure 8. The effects of pimozide (PMZ) $\left(10^{-5} \mathrm{M}\right)$ plus trifluoperazine (TFP) $\left(10^{-5} \mathrm{M}\right)$ on gastrin-stimulated oxyntic cell HIP. ${ }^{*}$ Indicates significant differences between gastrin alone and gastrin plus PMZ or TFP $(P<0.05)$. 


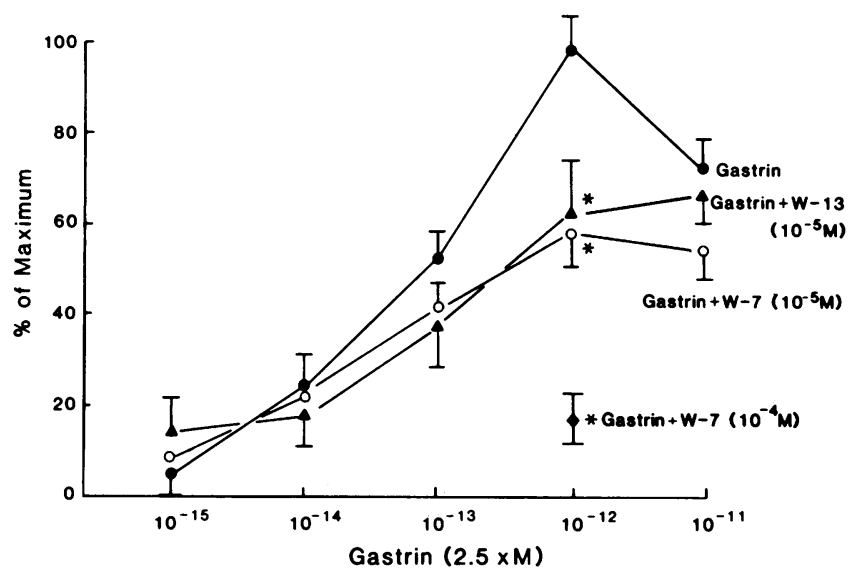

Figure 9. The effects of W-7 $\left(10^{-5} \mathrm{M}\right)$ and W-13 $\left(10^{-5} \mathrm{M}\right)$ on gastrinstimulated oxyntic cell HIP. ${ }^{*}$ Indicates significant differences between gastrin alone and gastrin plus W-7 or W-13 $(P<0.005)$.

significantly inhibited maximal gastrin-stimulated HIP ( $P$ $<0.005$ ) by 42.3 and $37.2 \%$, respectively. Increased doses of W-7 $\left(10^{-4} \mathrm{M}\right)$ had an even greater $(83 \%)$ inhibitory effect on maximal gastrin-stimulated HIP, whereas this dose of W13 had no greater an inhibitory effect.

Cellular mechanisms of action of gastrin. The cellular mechanisms whereby gastrin stimulates oxyntic HIP were further investigated using agents which inhibit carbonic anhydrase activity (acetazolamide), an inhibitor of respiration ( $\mathrm{NaSCN}$ ) (27), and a compound that neutralizes proton pump activity (H149/ 94). Acetazolamide $\left(10^{-5} \mathrm{M}\right), \mathrm{NaSCN}\left(10^{-4} \mathrm{M}\right)$, and Hassle compound $(\mathrm{H} 149 / 94)\left(10^{-4} \mathrm{M}\right)$ were added to a $D_{\max }$ dose of gastrin $\left(10^{-12} \mathrm{M}\right)$. As shown in Fig. 10, gastrin-stimulated HIP was significantly inhibited by acetazolamide, $\mathrm{NaSCN}$, and $\mathrm{H149}$ / $94(P<0.001)$.

\section{Discussion}

Quantitative cytochemistry has been shown to provide sensitive, quantitative measurement of hydroxyl ion production in guinea pig oxyntic cells $(15,18,19,21)$. The reaction, which depends upon trapping of $\mathrm{OH}$ ions produced, can be blocked by the carbonic anhydrase inhibitor, acetazolamide, and the benzimidazole Hassle $\mathrm{H} 149 / 94$, which inhibits the $\mathrm{K}^{+} \mathrm{H}^{+}$-ATPase (28). Although this does not represent a direct measurement of the activity of either carbonic anhydrase or the $\mathrm{K}^{+}+\mathrm{H}^{+}$-ATPase and acid secretion, all models for proton secretion by the cell require the concommitant release of an hydroxyl ion within the cell, and measurement of HIP by this technique may well reflect acid secretion (8). Stimulation of oxyntic cell HIP was specific for the biologically active analogues of gastrin. NHG34 (sulfated and nonsulfated) and the $\mathrm{COOH}$-terminus fragment of the gastrin molecule were active in stimulating HIP, whereas the inactive $\mathrm{NH}_{2}$-terminal fragment of the gastrin molecule had no effect. The specificity of the response to gastrin was demonstrated by inhibition of its action by an antiserum directed towards the biologically active $\mathrm{COOH}$-terminus. The $\mathrm{COOH}$ terminal octapeptide of $\mathrm{CCK}^{8}$ had similar efficacy, but it reduced potency, as had been reported (29), and may be due to increased release of endogenous somatostatin by $\mathrm{CCK}^{8}$, as compared with gastrin (30). The equivalent stimulation by $\mathrm{COOH}$-terminal fragments and $\mathrm{G} 17$ in vitro contrasts with the reduced potency of gastrin fragments in vivo $(1,2)$ and is compatible with the rapid in vivo hepatic inactivation of gastrin fragments of eight amino acids or less.

The reason for the inordinate sensitivity of the oxyntic cells to gastrin in this assay is not clear, but has been observed by several authors $(18,20,26)$. It does not appear to be due to concentration of the secretagogues at the respective cell membrane receptor, since we have not been able to demonstrate enhanced uptake of cold or radiolabeled gastrin by this procedure. Furthermore, it is unlikely that freezing the cells causes disruption of cell membranes, which precludes binding of gastrin to the oxyntic cell membrane. Using a similar freeze-thaw technique, Penney et al. (31) have shown binding of ${ }^{3} \mathrm{H}$-muscimol to sections of rat brain and have demonstrated that cell membranes were not disrupted by this technique. Direct action of gastrin on bovine erythrocyte carbonic anhydrase has been shown, but it requires micromolar concentrations of gastrin (32), which suggests that intact cell function is required for amplification of the signal. Similar sensitivities have been reported in validated quantitative cytochemical bioassays for ACTH, parathyroid hormone, and thyroid-stimulating hormone in sections of adrenal, kidney, and thyroid (33-35).

Gastrin activation of HIP appears to be biphasic, with a rapid response at $90 \mathrm{~s}$ and a later phase maximal at $240 \mathrm{~s}$. All the current studies relate to the early phase. It is not clear at

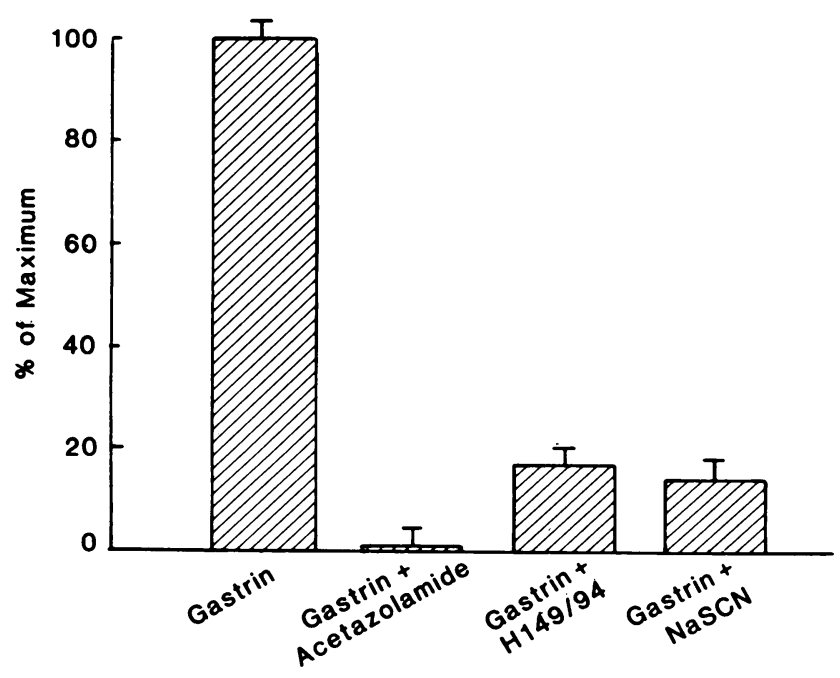

Figure 10. The effects of acetazolamide $\left(10^{-5} \mathrm{M}\right), \operatorname{NaSCN}\left(10^{-4} \mathrm{M}\right)$ and $\mathrm{H} 149 / 94\left(10^{-4} \mathrm{M}\right)$ on maximal gastrin-stimulated HIP. 
present whether factors regulating these two phases of HIP are the same, and it will be of interest to study the second phase.

Cimetidine blocked $23 \%$ of the activity of gastrin. This significant reduction in the maximal effect of gastrin by cimetidine may be due to blocking of the actions of endogenous histamine (36). Alternatively, gastrin may activate histamine release from unidentified paracrine cells that are located near the oxyntic cell, and this may modulate the response to gastrin. Similar, albeit quantitatively, slightly different results using rabbit gastric glands have been reported (17). In isolated canine parietal cells, however, the small degree of stimulation of ${ }^{14} \mathrm{C}$-aminopyrine accumulation (11) and increase in oxygen consumption (37) by gastrin was not blocked by cimetidine.

Atropine had no effect on gastrin-stimulated HIP, which suggests that gastrin does not act through a muscarinic cholinergic mechanism. In studies reported elsewhere (26), we have shown that atropine completely abolished the effects of carbachol, which provides evidence that this system responds to cholinergic agents.

The role of $\mathrm{Ca}^{2+}$ in gastrin-stimulated HIP was examined by using EGTA and $\mathrm{LaCl}_{3}$. EGTA chelates extracellular $\mathrm{Ca}^{2+}$ and renders it biologically inactive. $\mathrm{LaCl}_{3}$ displaces membranebound $\mathrm{Ca}^{2+}$ and thereby alters $\mathrm{Ca}^{2+}$ flux without penetrating intracellularly (38). EGTA and $\mathrm{LaCl}_{3}$ reduced the action of gastrin by 67 and $52 \%$, respectively, suggesting that gastrin stimulation of the oxyntic cell is partially dependent upon extracellular $\mathrm{Ca}^{2+}$. These findings are consistent with studies that report $\mathrm{Ca}^{2+}$ dependence of secretagogue action in isolated canine parietal cells (39) and in isolated rabbit gastric glands (9). EGTA also inhibited maximal $\mathrm{Ca}^{2+}$-stimulated HIP in a dose dependent but not stoichmetric manner, presumably because of endogenous $\mathrm{Ca}^{2+}$, but $10^{-3}$ M EGTA completely abolished the $\mathrm{Ca}^{2+}$ effect. The effects of EGTA and the $\mathrm{Ca}^{2+}$ channel blocker, $\mathrm{LaCl}_{3}$, suggests that extracellular $\mathrm{Ca}^{2+}$ is important for the action of gastrin. Increasing the extracellular $\mathrm{Ca}^{2+}$ caused a significant increase in gastrin-stimulated HIP at low concentrations of the dose-response curve. The effects were additive, which suggests that the two agonists act on a similar pathway. The ionophore, A23187, which accelerates fluxes of $\mathrm{Ca}^{2+}$ and other divalent cations across biological as well as artificial membranes (40), inhibited gastrin action by $45 \%$. In addition, A23187 caused a significant increase in basal activity, presumably by increasing cytosolic $\mathrm{Ca}^{2+}$ or by a mechanism as yet unknown. Since EGTA and $\mathrm{LaCl}_{3}$ do not affect intracellular $\mathrm{Ca}^{2+}$ events, the possibility remained that gastrin may act via $\mathrm{Ca}^{2+}$ mechanisms within the cell.

Calmodulin is an intracellular $\mathrm{Ca}^{2+}$-binding protein that regulates $\mathrm{Ca}^{2+}$-dependent cellular events and $\mathrm{Ca}^{2+}$ movements within the cell (41). Trifluoperazine and pimozide are two hydrophobic drugs that bind to calmodulin and render it biologically inactive $(41,42)$. Trifluoperazine and pimozide reduced HIP stimulated by gastrin by 45.6 and $38.5 \%$, respectively, which suggests that calmodulin plays an important role in mediating the effects of gastrin on the oxyntic cell. Since, however, these drugs are highly lipid soluble, their effects may result in disruption of cell membrane receptors for gastrin (43). Additional studies were performed using W-7 and W-13, two naphthalenesulfonamides, which have been reported to inhibit calmodulin without causing cell membrane or cytoskeletal changes (44). At high doses, W-7 and W-13 significantly inhibited maximal gastrinstimulated HIP by 83.1 and $67.1 \%$, respectively. Recent studies indicate that W-7, commonly regarded as a calmodulin antagonist, also inhibited the phospholipid-sensitive $\mathrm{Ca}^{2+}$-dependent protein kinases (45), which may account for the greater inhibition of gastrin-stimulated HIP observed with W-7. Thus, the rapid activation of HIP by gastrin observed at $90 \mathrm{~s}$ may be due in part to activation of the phospholipid-sensitive of $\mathrm{Ca}^{2+}$-dependent, protein kinase system. Trifluoperazine and pimozide significantly inhibited the effects of supramaximal doses of gastrin, whereas the naphthalenesulfonamides had no effects thereon. Although these findings are consistent with a nonspecific membrane action of trifluoperazine and pimozide, it is also possible that pathways of oxyntic cell activation differ at each dose level of gastrin.

Acetazolamide $\left(10^{-5} \mathrm{M}\right)$ completely inhibited gastrin-stimulated HIP, which indicates that carbonic anhydrase is activated during stimulation of the oxyntic cell by gastrin. The intimate association of the enzyme with the microvilli of the secretory canaliculi suggests that carbonic anhydrase plays an integral role in acid secretion by rapidly converting the $\mathrm{OH}$ ions produced on the cytosolic surface of the proton pump to $\mathrm{HCO}_{3}$. In these studies, we have shown that the substituted benzimidazole (H149/94) abolished gastrin-stimulated HIP, which supports the notion that gastrin action culminates in proton pump activation, since H149/94 has been shown to directly inhibit the gastric $\mathrm{H}^{+}+\mathrm{K}^{+}$-ATPase, the presumed proton pump (28). The tissue concentration of ATP in the sections is $0.19 \mathrm{mM} / \mathrm{g}$, which is enough to support proton pump activity. NaSCN also abolished the action of gastrin. However, the mechanism of action of $\mathrm{NaSCN}$ is unclear. NaSCN may inhibit acid secretion by increasing the rate of proton-gradient dissipation (27), may restrict access of $\mathrm{OH}$ ions to the enzyme (8), or may have a direct inhibitory action on carbonic anhydrase (46).

Our data suggests that gastrin acts via a receptor-mediated mechanism which is separate from that of histamine and acetylcholine on the oxyntic cell, as has been suggested by Soll et

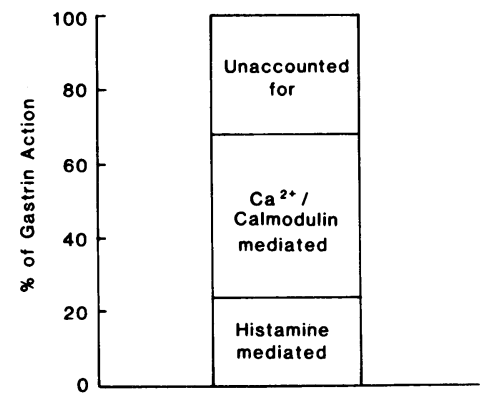

Figure 11. Schematic representation of gastrin stimulation of oxyntic cell HIP. The total response is ascribed an arbitrary value of $100 \%$ and consists of three components: a histaminemediated component blocked by cimetidine; a $\mathrm{Ca}^{2+}$-Calmodulin component blocked by EGTA, $\mathrm{LaCl}_{3}$, trifluoperazine, pimozide, and naphthalenesulfonamides; and an unknown component that may involve direct action of gastrin on the oxyntic cell. 
al. (10-12) and Chew and Hersey (17). On the basis of our results, we propose that gastrin stimulates HIP through three separate pathways (Fig. 11). Gastrin acts partly through a histamine-adenylate cyclase mechanism. It may interact directly with endogenous histamine upon the oxyntic cell, potentiate the histamine pathway, or may stimulate histamine release from adjacent histamine-containing cells. The second pathway is largely through an extracellular and intracellular $\mathrm{Ca}^{2+}$-dependent mechanism. These two pathways account for $\sim 70 \%$ of the stimulatory mechanism of action of gastrin. Further studies should reveal the nature of the residual activity.

\section{Acknowledgments}

This work was supported by a grant from the National Institutes of Health (U. S. Public Health Service-AM-27077-02).

\section{References}

1. Walsh, J. H., and M. I. Grossman. 1975. Gastrin (Pts. I and II). N. Engl. J. Med. 292:1324-1332, 1337-1384. 104.

2. Walsh, J. H. 1975. Circulating gastrin. Annu. Rev. Physiol. 37:81-

3. Rehfeld, J. F. 1979. Gastrointestinal hormones. In International Revue of Physiology. Gastrointestinal Physiol. III. R. K. Crane, editor. Universal Park Press, Baltimore. 19:291-321.

4. Nillson, G., R. S. Yalow, and S. A. Berson. 1973. Distribution of gastrin in the gastrointestinal tract of human, dog, cat and hog. In Frontiers of Gastrointestinal Research. S. Anderson, editor. Almqrist \& Wiksell, Stockholm, Sweden. 95-101.

5. Tracy, H. J., and R. A. Gregory. 1964. Physical properties of a series of synthetic peptides structurally related to gastrin. I. Nature (Lond.). 204:935-938.

6. Soll, A. H., and J. H. Walsh. 1978. Regulation of gastric acid secretion. Annu. Rev. Physiol. 41:35-53.

7. Takeuchi, K., G. Speir, and C. R. Johnson. 1979. Mucosal gastrin receptor. II. Physical characteristics of binding. Am. J. Physiol. 237(3):E295-E300.

8. Sachs, G., and T. Berglindh. 1981. Physiology of the parietal cell. In Physiology of the Gastrointestinal Tract. Leonard J. Johnson, editor. Raven Press, New York. 567-602.

9. Berglindh, T., G. Sachs, and N. Takeguchi. 1980. $\mathrm{Ca}^{2+}$-dependent secretagogue stimulation in isolated rabbit gastric glands. Am. J. Physiol. 239:G90-G94.

10. Soll, A. H., and A. Wollin. 1979. Histamine and cyclic AMP in isolated canine parietal cells. Am. J. Physiol. 237:E444-E450.

11. Soll, A. H. 1980 . Secretagogue stimulation of $\left[{ }^{14} \mathrm{C}\right]$-aminopyrine accumulation by isolated canine parietal cells. Am. J. Physiol. 238:G366G375.

12. Soll, A. H. 1978. Three-way interactions between histamine, carbachol and gastrin on aminopyrine uptake by isolated parietal cells. Gastroenterology. 74:1146. (Abstr.)

13. Sonnenberg, A., T. Berglindh, M. J. M. Lewin, J. A. Fisher, G. Sachs, and A. L. Blum. 1979. Stimulation of acid secretion in isolated gastric cells. In Hormone Receptors in Digestion and Nutrition. G. Rosselin, P. Fromengeot, and S. Bonfils, editors. Elsevier/North Holland Biomedical Press, New York. 337-348.

14. Salganik, R. I., R. I. Bersimbaev, S. V. Argutinskaya, E. V. Kiseleva, N. B. KhristoLyubova, and V. I. Deribas. 1976. Integration of biochemical functions of different cells of rat gastric mucosa for hydrochloric secretion. Mol. Cell Biochem. 12:181-191.

15. Lonnerholm, G. 1975. Carbonic anhydrase histochemistry-a critical study of Hansson's cobalt-phosphate method. Acta Physiol. Scand. Suppl. 418:1-43.

16. Maclntosh, F. C. 1938. Histamine as a normal stimulant of gastric secretion. Q. J. Exp. Physiol. 28:87-98.

17. Chew, C. S., and S. J. Hersey. 1982. Gastrin stimulation of isolated gastric glands. Am. J. Physiol. 242:G504-G512.

18. Loveridge, N., S. R. Bloom, R. B. Welbourn, and J. Chayen. 1974. Quantitative cytochemical estimation of the effect of pentagastrin $(.005-5 \mathrm{pg} / \mathrm{ml})$ and of plasma gastrin in the guinea pig fundus in vitro. Clin. Endocrinol. 3:389-396.

19. Loveridge, N. 1978. A quantitative cytochemical method for measuring carbonic anhydrase. Histochem. J. 10:361-372.

20. Walker, W., A. Vinik, A. Heldsinger, and R. Kaveh. 1983. The role of calcium and calmodulin in activation of the oxyntic cell by histamine and carbamylcholine in the guinea pig. J. Clin. Invest. 72:955964.

21. Shapiro, B., K. Pienta, A. Heldsinger, and A. I. Vinik. 1981. Somatostatin is an agonist and noncompetitive antagonist of gastrin in oxyntic cell function. Endocrinology. 109:1117-1121.

22. Sabina, R. L., J. L. Swain, B. M. Patten, T. Ashizawa, W. E. O'Brien, and E. W. Holmes. 1980. Disruption of purine nucleotide cycle. J. Clin. Invest. 66:1419-1423.

23. Hansson, H. P. J. 1967. Histochemial demonstration of carbonic anhydrase activity. Histochem. J. 11:112-128.

24. Vinik, A. I., B. J. Grant, and B. Novis. 1975. Gastrins in human antrum, duodenum and peripheral circulation. S. Afr. Med. J. 49:255257.

25. Vinik, A. I., A. Heldsinger, and M. L. Skoglund. 1983. Evidence for Histamine $\mathrm{H}_{1}$ and $\mathrm{H}_{2}$ receptors in guinea pig oxyntic cells. J. Pharmacol. Exp. Ther. 221(1):115-121.

26. Klaff, L. J., A. I. Vinik, and A. Heldsinger. 1981. Acid secretagogue potencies and interaction in the activation of carbonic anhydrase in guinea pig parietal cells. In Neuropeptides. Biochemical and Physiological Studies. R. P. Millar, editor. Churchill Livingstone, New York. 35:336343.

27. Hersey, S. J., C. S. Chew, L. Campbell, and E. Hopkins. 1981. Mechanism of action of SCN in isolated gastrin glands. Am. J. Physiol. 240:9232-9238.

28. Fellenius, E., T. Berglindh, G. Sachs, L. Olbe, B. Elander, S. E. Sjostrand, and B. Wallmark. 1981. Substituted benzimidazoles inhibit acid secretion by blocking the $\mathrm{H}^{+} \mathrm{K}^{+}$-ATPase. Nature (Lond.). 290:159161.

29. Loveridge, W., L. Bitensky, and J. Chayen. 1981. A possible biological role of the "biologically inactive" region of polypeptide hormones. J. Immunoassay. 2:89-97.

30. Soll, A. H., D. Amirian, J. Park, V. Thomas, and T. Yamada. 1983. CCK/Gastrin receptors in canine fundic mucosal cells. Gastroenterology. 84(5):1315. (Abstr.)

31. Penney, J. B., H. S. Pan, A. B. Young, K. A. Frey, and G. W. Dauth. 1981. Quantitative autoradiography of $\left[{ }^{3} \mathrm{H}\right]$-muscinol binding in rat brain. Science (Wash. DC). 214:1036-1038.

32. Puscas, I., A. Chiu, G. H. Buzas, L. Voicu, P. Contrasiv, G. Mihalas, L. Veress, M. Chiss, P. Suranyi, M. Domuta, M. Simonca, O. Arelean, O. Pascu, and M. Rocsin. 1980. Contributions to the elucidation of gastric acid secretory mechanisms, carbonic anhydrase and histamine $\mathrm{H}_{2}$ receptors. Rev. Roum. Biochim. 17(1):57-75. 
33. Daly, J. R., J. Alaghband-Zadeh, N. Loveridge, and J. Chayen. 1977. Cytochemical bioassay of ACTH. Ann. NY Acad. Sci. 297:242259.

34. Bitensky, L., J. Alaghband-Zadeh, and J. Chayen. 1974. Studies on thyroid stimulatory hormone and the long-acting thyroid stimulating hormone. Clin. Endocrinol. 3:363-374.

35. Chambers, D. J., J. Dunham, J. M. Zanelli, J. A. Parson, L. Bittensky, and J. Chayen. 1978. A sensitive bioassay of parathyroid hormone in plasma. Clin. Endocrinol. 9:375-379.

36. Soll, A. H., K. Lewin, and M. A. Beaven. 1979. Isolation of histamine containing cells from canine fundic tissue. Gastroenterology. 77:1283-1290.

37. Soll, A. H. 1978. The action of secretagogues on oxygen uptake by isolated mammalian parietal cells. J. Clin. Invest. 61:370-380.

38. Langer, G. A., and J. S. Frank. 1972. Lanthanum in heart cell culture: effect on calcium exchange correlated with its localization. $J$. Cell Biol. 54:441-445.

39. Soll, A. H. 1981. Extracellular calcium and cholinergic stimulation of isolated canine parietal cells. J. Clin. Invest. 68:270-278.
40. Reed, P. W., and H. A. Lardy. 1972. A23187: a divalent cation ionophore. J. Biol. Chem. 247:6970-6977.

41. Cheung, W. Y. 1980. Calmodulin plays a pivotal role in cellular regulation. Science (Wash. DC). 207:19-27.

42. Conn, P. M., C. D. Rogers, and T. Sheffield. 1981. Inhibition of gonadotropin releasing hormone-stimulated luteinizing hormone release by pimozide: evidence for a site of action after calmodulin mobilization. Endocrinology. 109(4):1122-1126.

43. Osborn, M., and K. Weber. 1980. Damage of cellular functions by trifluoperazine, a calmodulin-specific drug. Exp. Cell Res. 130:484487.

44. Hidaka, H., M. Asano, and T. Tanaka. 1981. Activity-structure relationship of calmodulin antagonists: naphthalenesulfonamide derivatives. Mol. Pharmacol. 20:571-578.

45. Schatzman, R. C., R. L. Raynor, and J. K. Kuo. 1983. N-(6Aminohexyl)-5-chloro-1-naphthalenesulfonamide (W-7), a calmodulin antagonist, also inhibits phospholipid-sensitive calcium-dependent protein kinase. Biochim. Biophys. Acta. 775:144-147.

46. Maren, T. H. 1967. Carbonic anhydrase: chemistry, physiology and inhibition. Physiol. Rev. 47:597-781. 